Magdalena Kot-RadojewsKa

Wyższa Szkoła Biznesu

w Dąbrowie Górniczej

\title{
ZINTEGROWANY SYSTEM WSPARCIA STUDENTÓW WE WSPÓŁCZESNEJ EDUKACJI - DOBRE PRAKTYKI
}

\begin{abstract}
AвSTRACT. Kot-Radojewska Magdalena, Zintegrowany system wsparcia studentów we wspótczesnej edukacji - dobre praktyki [An Integrated System of Student Support in Modern Education - Good Practices]. Studia Edukacyjne nr 47, 2018, Poznań 2018, pp. 185-195. Adam Mickiewicz University Press. ISSN 1233-6688. DOI: $10.14746 /$ se.2018.47.12

The paper argues about the role of higher education not only in terms of knowledge transfer and acquisition of vocational skills among young people, that is, the creation of qualified human capital for the needs of the economy, but also in terms of implementation of the educational role of the university, one currently underrated. It is aimed at the education of creative, open-minded, responsible graduates, capable of understanding a dynamically changing reality, able to adapt to changes flexibly, and accept responsibility for their own development. The article presents an example of good practices in the field of comprehensive student support in higher education as developed by the University of Dąbrowa Górnicza. This approach, in addition to improving the professional potential of students, is also focused on forming their values, goals, attitudes and beliefs which will significantly affect their behavior and the way they use the acquired knowledge in the future.
\end{abstract}

Key words: education, socialization, human capital, knowledge, competences

\section{Wstęp}

Przez długi czas rolą edukacji było przekazywanie wiedzy oraz kształtowanie umiejętności. Obecnie jej celem jest przede wszystkim uczenie, jak się uczyć oraz formowanie postaw. Kluczowe dla realizacji tego celu jest kształcenie aktywności, wyobraźni, zdolności do intelektualnej autonomii i nieustannej edukacji ${ }^{1}$, co wyraża się w stwarzaniu możliwości do kształcenia ustawicznego przez całe życie. Jak wskazuje C. Banach, edukacja

${ }^{1}$ B. Kołaczek, Dostęp młodzieży do edukacji. Zróżnicowania. Uwarunkowania. Wyrównanie szans, Warszawa 2004, s. 16. 
(...) jest społeczną wartością i kapitałem oraz nadzieją, a także wielkim obszarem zadań. Powinna być także w swych celach i metodach pracy poważnym sprzeciwem wobec wielu antywartości oraz negatywnych zjawisk i zagrożeń ludzkiego bytu².

Edukacja z jednej strony jest czynnikiem niezbędnym dla kształtowania tożsamości człowieka, z drugiej - koniecznym warunkiem twórczego i naturalnego rozwoju ${ }^{3}$.

Coraz częściej postrzega się edukację jako „dobro inwestycyjne”, a nie tylko „dobro konsumpcyjne" ${ }^{4}$. Oprócz „dostarczania” wykwalifikowanych pracowników na rynek pracy, edukacja powinna rozwijać uzdolnienia i umiejętności każdego człowieka, odkrywać, pobudzać i wzmacniać jego potencjał twórczy.

\section{Wyzwania edukacji XXI wieku w kontekście kreowania kapitału ludzkiego}

Jakość kapitału ludzkiego, rozumianego jako wiedza „zawarta” w ludziach $^{5}$, zależy w znaczącej mierze od jakości edukacji, zwłaszcza szkolnictwa wyższego. Kapitał ludzki, określany też jako zespół wszystkich cech ludzkich, może generować zysk ekonomiczny. Wskazane cechy ludzkie odnoszą się do aspektów formalnych (np. edukacja formalna, szkolenia), jak również elementów mniej formalnych (np. kompetencje, umiejętności, talent, motywacja, czy wytrwałość) ${ }^{6}$. Kapitał ludzki cechuje możliwość powiększania się, czyli wzrostu jego wartości w procesie uczenia się w systemie edukacji, ale również możliwość zużywania się tegoż kapitału, co jest konsekwencją zaniechania kształcenia się w opozycji do wciąż postępującego procesu rozwoju wiedzy ${ }^{7}$. Strategicznym wyzwaniem dla współczesnej edukacji wyższej powinno być wyposażenie studentów $\mathrm{w}$ wiedzę niezbędną do budowania konkurencyjności polskiej gospodarki opartej na wiedzy, czyli takiej, w któ-

${ }^{2}$ C. Banach, Społeczeństwo polskie wobec wyzwań transformacji systemowej, [w:] Koreferaty, Komitet Prognoz „Polska w XXI wieku” przy Prezydium PAN, Warszawa 1998, s. 111.

${ }^{3}$ Encyklopedia pedagogiczna XXI w., t. 1, Warszawa 2003.

${ }^{4}$ A. Drapińska, Zarządzanie relacjami na rynku ustug edukacyjnych szkót wyższych, Warszawa 2012, s. 17.

${ }^{5}$ G. Becker, K. Murphy, R. Tamura, Human Capital, Fertility and Economic Growth, Journal of Political Economy, 1990, 98, s. 12.

${ }^{6}$ E. Tome, Human resource development in the knowledge based and services driven economy An introduction, Journal of European Industrial Training, 2011, 35. 6, , s. 524, http:/ / www.emeraldinsight.com/doi/pdfplus/10.1108/03090591111150077, [dostęp: 11.12.2017].

${ }^{7}$ B. Klimczak, Rola edukacji w przygotowaniu mobilnych i aktywnych uczestników rynku pracy [w:] Wybrane problemy i zastosowania ekonomii instytucjonalnej, red. B. Klimczak, Wrocław 2006, s. $127-128$. 
rej wiedza jest tworzona, zdobywana, ale również transmitowana i w sposób efektywny używana przez organizacje oraz jednostki dla rozwoju gospodarczego i społecznego ${ }^{8}$. Rolą edukacji wyższej powinno być przygotowywanie studentów do elastycznego funkcjonowania $\mathrm{w}$ turbulentnych warunkach współczesności i przyszłości. W tych warunkach fundamentalną rolę odgrywa praktyczne i elastyczne gromadzenie, przetwarzanie i kreowanie wiedzy, również tej istotnej dla właściwego kształtowania postaw życiowych i relacji międzyludzkich ${ }^{9}$. Wiedza powinna służyć lepszemu rozumieniu i kreowaniu rzeczywistości, o czym już w latach 60 . XX wieku pisał B. Suchodolski ${ }^{10}$.

Wyzwaniem dla edukacji jest też kształcenie młodych ludzi potrafiących podejmować racjonalne i odpowiedzialne działania $\mathrm{w}$ dziedzinie systematycznego doskonalenia i kształcenia ustawicznego, rozwiązywania problemów, rozumienia zmieniającej się rzeczywistości i elastycznego do niej dostosowania, podejmowania odpowiedzialności za własny rozwój, rozwijania przedsiębiorczości. Człowiek w XXI wieku powinien być racjonalny, dostrzegać i odpowiednio analizować procesy zachodzące w jego otoczeniu, właściwie na nie reagować i przystosowywać się do zmieniającej się rzeczywistości, zdawać sobie sprawę z tego, że w ramach kształcenia należy dbać nie tylko o rozwój umysłu, ale „całego człowieka"11.

W takim ujęciu wyzwań edukacyjnych konieczne staje się odejście od encyklopedycznego na rzecz generatywnego modelu kształcenia, w którym zakłada się, że student zostanie przygotowany

(...) do samodzielnego zdobywania, selekcjonowania, przetwarzania i przechowywania oraz racjonalnego posługiwania się zdobywanymi wiadomościami i umiejętnościami ${ }^{12}$. Bowiem (...) mądrość i wiedza nie zamieszkują w książkach, programach komputerowych czy Internecie. Tam są jedynie informacje. Mądrość i wiedza są zawsze ucieleśnione w człowieku, są zdobywane przez uczącą się osobę i przez nią wykorzystywane ${ }^{13}$.

W generatywnym modelu kształcenia student jest podmiotem wszystkich działań, a wykładowcy i mentorzy mają pobudzić jego aktywność oraz samodzielność, jak również wdrożyć do skutecznego rozwiązywania proble-

${ }^{8}$ E. Kryńska, E. Kwiatkowski, Podstawy wiedzy o rynku pracy, Łódź 2013, s. 161.

9 T.T. Brzozowski, Praca i przedsiębiorczość w świetle wybranych encyklik Jana Pawła II, [w:] Przedsiębiorczość a wspótczesne wyzwania cywilizacyjne, Przedsiębiorczość - Edukacja, nr 2, red. Z. Zioło, T. Rachwał, Warszawa - Kraków 2006.

${ }^{10}$ B. Suchodolski, Nowoczesna treść i organizacja wykształcenia ogólnego, Nowa Szkoła, 1958, 4.

${ }^{11}$ Cz. Kupisiewicz, Kanon wykształcenia ogólnego. Próba porównawczego zastosowania kierunków i dylematów przebudowy, [w:] Kanon kształcenia ogólnego, red. A. Bogaj, Warszawa 1995, s. $180-181$.

${ }_{12}$ B. Antczak, Wspótczesne tendencje tworzenia, dyfuzji i wykorzystania wiedzy, [w:] Dylematy wspótczesnej edukacji, red. K. Dziurzyński, Józefów 2012, s. 24.

${ }^{13}$ P.F. Drucker, Społeczeństwo pokapitalistyczne, Warszawa 1999, s. 171. 
mów teoretycznych i praktycznych. Podmiotowość studenta uczelni wyższej wyraża się w postrzeganiu go jako osoby, dostrzeżeniu jego tożsamości i docenieniu indywidualności, hierarchii jego wartości oraz celów. Student jako podmiot procesu kształcenia jest integralnie z tym procesem związany i wywiera na niego wpływ, rozumie oraz wspiera interakcje zachodzące $\mathrm{w}$ procesie kształcenia, określa cele i metody ich realizacji zgodnie z uznawanymi wartościami ${ }^{14}$.

Współczesny system kształcenia powinien uwzględniać edukację kluczowych umiejętności, które czynią ludzi zdolnymi do szybkiego uczenia się w ramach edukacji przez całe życie (life long learning). W kontekście dynamicznego postępu technologicznego, jaki zachodzi we współczesnych społeczeństwach, problemem dla ich funkcjonowania staje się szybka dezaktualizacja posiadanej wiedzy. Stąd, konieczne staje się uzupełnianie wiedzy i umiejętności oraz dostosowywanie ich do szybko zmieniających się uwarunkowań. Koncepcja uczenia się przez całe życie związana jest z kształceniem otwartym, niczym nie ograniczonym, dostosowaniem do potrzeb i możliwości, elastycznym, w którym charakterystyczny jest partnerski stosunek pomiędzy uczącym się i nauczającym, a jego celem jest rozwinięcie samodzielności i aktywności uczących się ${ }^{15}$.

\section{Socjalizacyjne i wychowawcze funkcje uczelni wyższej}

Oprócz funkcji dydaktycznej uczelni, czyli - jak wskazuje ustawa - kształcenia studentów $\mathrm{w}$ celu zdobywania i uzupełniania wiedzy oraz umiejętności niezbędnych w pracy zawodowej ${ }^{16}$, niezwykle istotne są funkcje socjalizacyjne i wychowawcze.

Socjalizacja jest procesem zachodzącym w różnych okresach życia jednostki, "dzieje” się również podczas edukacji wyższej. Dzięki socjalizacji jednostka rozwija się przez "transakcję" z innymi ludźmi oraz wzorami społecznego zachowania i doświadczenia ${ }^{17}$. Według J. Szczepańskiego,

socjalizacja kształtuje osobowość człowieka i przystosowuje go do życia w zbiorowości, umożliwia porozumienie się i inteligentne działanie w jej ramach, uczy, jak się

${ }^{14}$ A. Krajewska, Poczucie podmiotowości studentów w ocenie uczestników procesu ksztatcenia wyniki badań, [w:] Ewaluacja i innowacje w edukacji. Poprawa jakości ksztatcenia i jej uwarunkowania, red. J. Grzesiak, Kalisz - Konin 2012, s. 176.

${ }_{15}^{15}$ M. Pluta-Olearnik, Koncepcja Life - Long Learning - wyzwanie dla ksztatcenia na poziomie wyższym, s. 2, http://www.fundacja.edu.pl/organizacja/_referaty/33.pdf, [dostęp: 18.05.2015].

${ }^{16}$ Ustawa z 27 lipca 2005 r. Prawo o szkolnictwie wyższym (DzU 2017.02.183).

17 E. Zigler, L. Child, Socialization and Personality Development, Chicago 1973. 
zachowywać, by osiągnąć cele życiowe ${ }^{18}$. Socjalizacja to (...) kształtowanie osobowości społecznej albo nabywanie społecznej dojrzałości czy kompetencji społecznych ${ }^{19}$.

W procesie socjalizacji człowiek określa swoją tożsamość ${ }^{20}$, która według P.L. Bergera jest

(...) procesem, ciągle kreowanym i odtwarzanym w każdej sytuacji społecznej, w którą człowiek wkracza, spajanym przez wątłą nić pamięci ${ }^{21}$.

Pojęcie socjalizacji należy jednak odróżnić od pojęcia wychowania. Pod pojęciem socjalizacji rozumie się nie tylko zamierzone oddziaływania środowiska na osobę, ale również wszelkie inne wpływy, jakim ona podlega ${ }^{22}$. W odniesieniu do studentów wpływy te są następstwem uczestnictwa studentów w systemie społecznym szkoły wyższej, w którym zachodzi proces dzielenia się wiedzą i doświadczeniami z innymi ${ }^{23}$. To również „(..) przepływ wiedzy ukrytej między ludźmi” ${ }^{24}$, czyli tej, która jest w sposób szczególny zindywidualizowana, trudna do sformalizowania, głęboko zakorzeniona w indywidualnym sposobie działania, wartościach, osobistym nastawieniu i przekonaniach, w zakres której wchodzą intuicja, poglądy, przeczucia ${ }^{25}$. Wykorzystuje się ją podświadomie w codziennym działaniu, ma więc wymiar bardzo praktyczny. Nie można jej w pełni wyrazić za pomocą znaków, słów, czy liczb²6.

Wychowanie z kolei jest to intencjonalne kształtowanie osobowości na wzór przyjętego w danej grupie ideału wychowawczego oraz kształcenie, czyli przygotowanie jednostki do pełnienia określonej roli społecznej ${ }^{27}$. Z perspektywy uczelni wyższej wychowanie rozumiane jest jako dążenie do wyposażenia studenta w system postaw, ideałów, wartości i zasad, które wyznaczają jego stosunek do świata.

Wspomniane funkcje socjalizacyjne i wychowawcze są niestety wciąż słabo zakorzenione w świadomości zawodowej nauczycieli akademickich i władz uczelni. Niekiedy wręcz uważane jako zbędne w obliczu prawnej do-

\footnotetext{
18 J. Szczepański, Elementarne pojęcia socjologii, Warszawa 1967.

19 S. Kowalski, Socjologia wychowania w zarysie, Warszawa 1974, s. 295.

20 B. Szacka, Wprowadzenie do socjologii, Warszawa 2003, s. 138.

21 P.L. Berger, Zaproszenie do socjologii, Warszawa 1995, s. 102.

22 M. Pachociński, A. Słaboń, Słownik pojęć socjologicznych, Kraków 2001, s. 174.

23 J. Bogdanienko, W pogoni za nowoczesnością. Wybrane aspekty tworzenia $i$ wprowadzania zmian, Toruń 2008, s. 126.

24 A. Jashapara, Zarządzanie wiedza, Warszawa 2006, s. 254.

25 I. Nonaka, H. Takeuchi, Kreowanie wiedzy w organizacjach: jak spółki japońskie dynamizuja procesy innowacyjne, Warszawa 2000, s. 14-15.

${ }_{26}$ M. Wojnarowska, Zarzadzanie wiedza w organizacji, [w:] Koncepcje zarzadzania. Podręcznik akademicki, red. M. Czerska, A.A. Szpitter, Warszawa 2010, s. 325-326.

27 R.A. Podgórski, Socjologia. Wczoraj. Dziś. Jutro, Rzeszów 2006, s. 268.
} 
rosłości studentów oraz ich samodzielności ${ }^{28}$. W uczelni wyższej funkcje te polegają na kształtowaniu wartości, celów, postaw, przekonań, potrzeb i innych elementów, które wpłyną na postępowanie studiujących w przyszłości i sposób korzystania z nabytej wiedzy.

Rozważając wychowawcze oddziaływania uczelni na studentów, M. Nowak-Dziemianowicz wskazuje na trzy główne funkcje: adaptacyjną, emancypacyjną i krytyczną ${ }^{29}$. Funkcja adaptacyjna umożliwia socjalizację, pozwala odnaleźć się w rzeczywistości społecznej, regulowanej przez system norm i efektywnie w niej funkcjonować. Emancypacyjna pozwala na rozwój jednostki oraz wpływa na kształtowanie właściwych relacji z innymi oraz nadawanie im sensu. Umożliwia identyfikację nie tylko własnych możliwości i mocnych stron, ale także barier i ograniczeń. Ostania funkcja - krytyczna pozwala na interpretowanie rzeczywistości i własnych doświadczeń. Wyraża się w zadawaniu pytań o sens działań własnych i innych, a także o prawomocność tych działań.

Uczelnia realizująca te funkcje, jednocześnie kształtuje w swoich studentach pewne kompetencje społeczne ${ }^{30}$. Wśród kompetencji adaptacyjnych można wymienić między innymi umiejętność poszerzenia i przekazywania własnej wiedzy, efektywnego komunikowania się, negocjowania, współpracy w zespole, zarządzania czasem, czy dostosowywania się do zmian, a także przedsiębiorczość. W obszarze kompetencji emancypacyjnych można mówić o umiejętności aktywnego współżycia w społeczeństwie, przewidywania skutków własnej aktywności, formułowania i rozwiązywania problemów, akceptacji odmienności, szacunku do innych. Z kolei, za kompetencje krytyczne można uznać niezależność, zaangażowanie, odwagę, kreatywność, czy nonkonformizm.

Należy podkreślić, że współcześnie dostrzega się deficyt wskazanych kompetencji z punktu widzenia pracodawcó $w^{31}$, co potwierdzają wyniki licznych badań, na przykład Bilans Kapitału Ludzkiego ${ }^{32}$ i inne ${ }^{33}$. Niedopa-

${ }^{28}$ E. Wnuk-Lipińska, Uniwersytet dzisiaj - idea, cele, zadania, Nauka i Szkolnictwo Wyższe, 1996, 8, s. 14-15.

${ }_{29}$ M. Nowak-Dziemianowicz, Kompetencje społeczne jako jeden z efektów kształcenia w Krajowych Ramach Kwalifikacji w kontekście pytań o cele i funkcje edukacji, Warszawa 2012, s. 9.

${ }^{30}$ Tamże, s. 16-17.

${ }^{31}$ S. McGuinness, J. Bennett, Examining the link between skill shortages, training composition and productivity levels in the Northern Ireland construction industry, International Journal of Human Resource Management, 2006, 17, 2, s. 265-279.

${ }^{32}$ M. Kocór, A. Strzebońska, M. Dawid-Sawicka, Rynek pracy widziany oczami pracodawców. Raport z badania pracodawców i ofert pracy, Warszawa 2015, s. 10.

${ }^{33}$ Kompetencje i kwalifikacje poszukiwane przez pracodawców wśród absolwentów szkót wyższych wchodzacych na rynek pracy. Wyniki badania przeprowadzonego przez Szkołę Główną Handlową w Warszawie, Amerykańską Izbę Handlu w Polsce oraz Ernst \& Young, Warszawa 2012, s. 13, http://firma.sgh.waw.pl/pl/Documents/RKPK_raport_2012.pdf, [dostęp: 2.01.2018]. 
sowanie kompetencyjne znalazło się również na liście najbardziej ważkich wyzwań rozwoju kapitału ludzkiego wedle OECD ${ }^{34}$.

Zadaniem każdej uczelni powinno być umożliwienie studentom rozwoju oraz uwalniania ich potencjału w ramach różnego rodzaju aktywności proponowanych podczas realizowanego toku kształcenia. Uczelnia powinna tworzyć warunki, które sprzyjałyby przejawianiu aktywności własnej studentów oraz dokonywaniu świadomych i odpowiedzialnych wyborów. Powinna także stale podnosić ambicje edukacyjne studiujących oraz wzmacniać ich poczucie wartości własnej. Rolą uczelni powinno być także stwarzanie warunków do aktywnych interakcji pomiędzy nauczycielami i studentami, nie tylko w formie pracy nad zadaniami edukacyjnymi, ale również pod postacią coachingu czy mentoringu. Na koniec, student powinien mieć także możliwość zdobywania wiedzy cichej, nawiązywania i rozwijania kontaktów z autorytetami spoza uczelni, na przykład ze środowiska biznesu tak, by uczyć się właściwego pełnienia ról zawodowych w przyszłości.

\section{System wsparcia studentów realizowany w Wyższej Szkole Biznesu w Dąbrowie Górniczej}

W celu właściwego wsparcia i przygotowania absolwentów do funkcjonowania we współczesnej turbulentnej rzeczywistości i - jednocześnie - gospodarce opartej na wiedzy uczelnie powinny nie tylko nieustanie poszerzać programy kształcenia, ale również wzbogacać swoje działania o takie, które wyzwalają pozytywne emocje studentów i wzbogacają poczucie sensu podejmowanych przez nich aktywności ${ }^{35}$.

W Wyższej Szkole Biznesu w Dąbrowie Górniczej, w ścisłej współpracy z otoczeniem uczelni, od 10 lat realizowany jest autorski projekt wsparcia studentów. Wypracowane przez lata rozwiązanie pozwala doskonalić jakość kształcenia praktycznego i stymulować aktywizację zawodową studentów, a także wpływać na kształtowanie otwartych i elastycznych postaw młodych ludzi, sprawnie funkcjonujących w niestabilnym i niepodlegającym żadnym przewidywaniom środowisku. Podejmowane działania dodatkowo zwiększają konkurencyjność absolwentów na rynku pracy. Projekt opiera się na czterech filarach, do których należą:

${ }^{34}$ Better Skills, Better Jobs, Better Lives: A Strategic Approach to Skills Policies, OECD, 2012, http://www.keepeek.com/Digital-Asset-Management/oecd/education/better-skills-better-jobs-better-lives_9789264177338-en\#.WRtU0NwwjIU\#page4, [dostęp: 16.05.2017].

35 B. Kożusznik, M. Kożusznik, Praca, kariera $i$ studia w organizacjach nowego typu, [w:] Edukacja wobec rynku pracy i integracji europejskiej, red. K. Szczepańska-Woszczyna, Z. Dacko-Pikiewicz, Dąbrowa Górnicza 2007, s. 97. 
1. Intensywna i efektywna współpraca z pracodawcami, polegająca między innymi na: włączaniu pracodawców w proces określania i doskonalenia efektów kształcenia, programów studiów, metod walidacji efektów kształcenia; organizacji wizyt studyjnych, prezentujących nowoczesne rozwiązania biznesowe, organizacyjne, czy technologiczne, mające zastosowanie $\mathrm{w}$ przedsiębiorstwach reprezentujących branże odpowiadające danemu kierunkowi studiów; realizacji zajęć specjalistycznych przez pracodawców; upraktycznieniu studiów poprzez włączanie w proces dyplomowania pracodawców jako promotorów pomocniczych; realizacji specjalności studiów we współpracy z pracodawcami.

Współpraca $\mathrm{z}$ pracodawcami $\mathrm{w}$ ramach wymienionych działań służy wyposażeniu studentów w wiedzę oraz kompetencje zawodowe. Służy nawiązaniu procentujących w przyszłości interakcji z pracodawcami i przedsiębiorcami. Sprzyja także socjalizacji, rozumianej jako transfer wiedzy ukrytej, kształtowaniu kompetencji interpersonalnych oraz rozbudzaniu przedsiębiorczości studentów.

2. Działania doradcze, organizacyjne i szkoleniowe, w ramach których odbywają się między innymi warsztaty z dziedziny planowania kariery i doskonalenia poszukiwanych przez pracodawców kompetencji interpersonalnych oraz spotkania z doradcą zawodowym połączone z diagnozą predyspozycji osobowościowych; szkolenia specjalistyczne poszerzające kompetencje przydatne na rynku pracy, szkolenia przygotowujące do aktywnego poszukiwania pracy, długofalowe procesy coachingu kariery, branżowe, certyfikowane szkolenia specjalistyczne, dopasowane do specyfiki danego kierunku, szkolenia prowadzone przez przedstawicieli organizacji pozarządowych, akcje charytatywne.

Z wymienionych wyżej działań wynika, że program ma na celu nie tylko wyposażanie studentów w wiedzę i kompetencje, ale także umożliwienie im zdobywania pierwszych doświadczeń na rynku pracy. Celem jest również uświadomienie studentom konieczności wzięcia odpowiedzialności za własny rozwój zawodowy, wyposażenie ich w umiejętność przewidywania i zdolność elastycznego przystosowania się do zmian, co będzie skutkować ich większą konkurencyjnością. Szereg działań podejmowanych w ramach programu ma charakter wychowawczy, służąc kształtowaniu odpowiedzialności za siebie i innych, zaangażowania na rzecz różnych działań, nie tylko tych, których celem jest szeroko rozumiany zysk oraz oddziałując na rozwijanie postaw etycznych studentów.

3. Systemowe rozwiązanie w zakresie organizacji staży i praktyk, umożliwiające zindywidualizowane dopasowanie oferty praktyki do potrzeb studenta i pracodawcy.

Efektem działań w dziedzinie organizacji praktyk i staży jest skuteczne przygotowanie studentów do pełnienia roli pracownika, z naciskiem na pra- 
cownika wiedzy, czyli takiego, którego narzędziem pracy jest jego umysł ${ }^{36}$, a do jego cech charakterystycznych należą: autonomia, niezależność, samodzielność, mobilność oraz otwartość na zmiany ${ }^{37}$.

4. Wspieranie przedsiębiorczości studentów i absolwentów w ramach Zagłębiowskiego Inkubatora Przedsiębiorczości, którego celem jest wsparcie merytoryczne, finansowe oraz organizacyjne w zakładaniu oraz prowadzeniu działalności gospodarczej, profesjonalne doradztwo biznesowe oraz prawne, zintegrowana promocja firm funkcjonujących w strukturach Inkubatora.

Działania realizowane $\mathrm{w}$ ramach Zagłębiowskiego Inkubatora Przedsiębiorczości mają na celu przede wszystkim promowanie zachowań kreatywnych i przedsiębiorczych studentów, kreowanie postaw samodzielnych i odpowiedzialnych, wspieranie przedsiębiorczości lokalnej, będącej jednym z czynników sprzyjających rozwojowi regionu, a także wspieranie szybszego wzrostu nowych, często innowacyjnych przedsiębiorstw oraz eliminowanie ryzyka związanego z ich ewentualną upadłością.

Niewątpliwie, realizowany przez WSB zintegrowany system wsparcia studentów od wielu lat spełnia swoje zadania. Jednocześnie stale podlega ewaluacji i - na tej postawie - modyfikacjom podnoszącym jakość prowadzonych działań. Z perspektywy zawodowej - efektem wszystkich podejmowanych działań jest fakt, iż absolwenci WSB znajdują pracę w czasie krótszym niż miesiąc po zakończeniu studiów, czego dowodem jest czwarte miejsce pod względem zatrudnialności absolwentów w ogólnopolskim systemie monitorowania Ekonomicznych Losów Absolwentów szkół wyższych.

\section{Zakończenie}

Proces edukacji, intencjonalny bądź nie, towarzyszy człowiekowi przez całe jego życie. Stanowi nieodłączny element rozwoju człowieka, społeczeństwa, świata. Uczelnie powinny więc podejmować działania ukierunkowujące studentów na budowanie ich jednostkowej wartości rynkowej, wzbudzanie odpowiedzialności za kształtowanie własnego kapitału kariery oraz tożsamości profesjonalnej. Właściwie realizowana funkcja dydaktyczna na wyższym poziomie kształcenia jest nie do przecenienia dla kreowania wartości kapitału ludzkiego we współczesnej gospodarce opartej na wiedzy. Nie należy jednak zapominać o realizacji innych funkcji, takich jak funkcje socjalizacyjne i wychowawcze.

Z pewnością wciąż aktualne są cztery filary edukacji sformułowane w Raporcie dla UNESCO Międzynarodowej Komisji do spraw Edukacji dla

\footnotetext{
${ }^{36}$ T.H. Davenport, Zarządzanie pracownikami wiedzy, Kraków 2007, s. 22-23.

${ }^{37}$ M. Morawski, Zarzadzanie profesjonalistami, Warszawa 2009, s. 54.
} 
XXI wieku pod przewodnictwem Jacques'a Delorsa: uczyć się, aby wiedzieć, uczyć się, aby działać, uczyć się, aby żyć wspólnie, uczyć się, aby być38. Tylko pełna realizacja tych czterech aspektów kształcenia umożliwia całkowite urzeczywistnienie misji edukacji.

\section{BIBLIOGRAFIA}

Antczak B., Wspótczesne tendencje tworzenia, dyfuzji i wykorzystania wiedzy, [w:] Dylematy wspótczesnej edukacji, red. K. Dziurzyński, Wydawnictwo Wyższej Szkoły Gospodarki Euroregionalnej, Józefów 2012.

Banach C., Społeczeństwo polskie wobec wyzwań transformacji systemowej, [w:] Koreferaty, Komitet Prognoz „Polska w XXI wieku” przy Prezydium PAN, Warszawa 1998.

Becker G., Murphy K., Tamura R., Human Capital, Fertility and Economic Growth, Journal of Political Economy, 1990, 98.

Berger P.L., Zaproszenie do socjologii, Państwowe Wydawnictwo Naukowe, Warszawa 1995. Better Skills, Better Jobs, Better Lives: A Strategic Approach to Skills Policies, OECD, 2012, http:/ / www.keepeek.com/Digital-Asset-Management/oecd/education/better-skills-better-jobs-better-lives_9789264177338-en\#.WRtU0NwwjIU\#page4, [dostęp: 16.05.2017].

Bogdanienko J., W pogoni za nowoczesnościa. Wybrane aspekty tworzenia i wprowadzania zmian, Towarzystwo Naukowe Organizacji i Kierownictwa, Torun 2008.

Brzozowski T.T., Praca i przedsiębiorczość w świetle wybranych encyklik Jana Pawła II, [w:] Przedsiębiorczość a wspótczesne wyzwania cywilizacyjne. Przedsiębiorczość - Edukacja, nr 2, red. Z. Zioło, T. Rachwał, Nowa Era, Zakład Przedsiębiorczości i Gospodarki Przestrzennej Instytutu Geografii Akademii Pedagogicznej w Krakowie, Warszawa - Kraków 2006.

Davenport T.H., Zarzadzanie pracownikami wiedzy, Wydawnictwo Oficyna Wolters Kluwer Business, Kraków 2007.

Drapińska A., Zarządzanie relacjami na rynku ustug edukacyjnych szkót wyższych, Wydawnictwo Naukowe PWN, Warszawa 2012.

Drucker P.F., Społeczeństwo pokapitalistyczne, Wydawnictwo Naukowe PWN, Warszawa 1999.

Encyklopedia pedagogiczna XXI w., t. 1, Wydawnictwo Akademickie Żak, Warszawa 2003.

Jashapara A., Zarządzanie wiedza, Polskie Wydawnictwo Ekonomiczne, Warszawa 2006.

Klimczak B., Rola edukacji w przygotowaniu mobilnych i aktywnych uczestników rynku pracy, [w:] Wybrane problemy i zastosowania ekonomii instytucjonalnej, red. B. Klimczak, Wydawnictwo Akademii Ekonomicznej, Wrocław 2006.

Kocór M., Strzebońska A., Dawid-Sawicka M., Rynek pracy widziany oczami pracodawców, Raport z badania pracodawców i ofert pracy, PARP, Warszawa 2015.

Kołaczek B., Dostęp młodzieży do edukacji. Zróżnicowania. Uwarunkowania. Wyrównanie szans, IPiSS, Warszawa 2004.

Kompetencje i kwalifikacje poszukiwane przez pracodawców wśród absolwentów szkót wyższych wchodzacych na rynek pracy, Wyniki badania przeprowadzonego przez Szkołę Główną Handlową w Warszawie, Amerykańską Izbę Handlu w Polsce oraz Ernst \& Young,

${ }^{38}$ Raport dla UNESCO Międzynarodowej Komisji do spraw Edukacji dla XXI wieku pod przewodnictwem Jacques'a Delorsa „Edukacja: jest w niej ukryty skarb”, http:/ / www.unesco.pl/ fileadmin/user_upload/pdf/4_Filary_Raport_Delorsa.pdf [dostęp: 2.01.2018]. 
Warszawa 2012, s. 13, http://firma.sgh.waw.pl/pl/Documents/RKPK_raport_2012. pdf, [dostęp: 2.01.2018].

Kowalski S., Socjologia wychowania w zarysie, Państwowe Wydawnictwo Naukowe, Warszawa 1986.

Kożusznik B., Kożusznik M., Praca, kariera i studia w organizacjach nowego typu, [w:] Edukacja wobec rynku pracy i integracji europejskiej, red. K. Szczepańska-Woszczyna, Z. DackoPikiewicz, Wydawnictwo Wyższej Szkoły Biznesu w Dąbrowie Górniczej, Dąbrowa Górnicza 2007.

Krajewska A., Poczucie podmiotowości studentów w ocenie uczestników procesu kształcenia wyniki badań, [w:] Ewaluacja i innowacje w edukacji. Poprawa jakości ksztatcenia i jej uwarunkowania, red. J. Grzesiak, Uniwersytet im. A. Mickiewicza w Poznaniu, Państwowa Wyższa Szkoła Zawodowa w Koninie, Kalisz - Konin 2012.

Kryńska E., Kwiatkowski E., Podstawy wiedzy o rynku pracy, Wydawnictwo Uniwersytetu Łódzkiego, Łódź 2013.

Kupisiewicz Cz., Kanon wyksztatcenia ogólnego. Próba porównawczego zastosowania kierunków i dylematów przebudowy, [w:] Kanon kształcenia ogólnego, red. A. Bogaj, Warszawa 1995.

McGuinness S., Bennett J., Examining the link between skill shortages, training composition and productivity levels in the Northern Ireland construction industry, International Journal of Human Resource Management, 2006, 17, 2.

Morawski M., Zarządzanie profesjonalistami, Polskie Wydawnictwo Ekonomiczne, Warszawa 2009.

Nonaka I., Takeuchi H., Kreowanie wiedzy w organizacjach: jak spółki japońskie dynamizuja procesy innowacyjne, Wydawnictwo Poltext, Warszawa 2000.

Nowak-Dziemianowicz M., Kompetencje społeczne jako jeden z efektów ksztatcenia w Krajowych Ramach Kwalifikacji w kontekście pytań o cele i funkcje edukacji, Instytut Badań Edukacyjnych, Warszawa 2012.

Pachociński M., Słaboń A., Słownik pojęć socjologicznych, Wydawnictwo Akademii Ekonomicznej w Krakowie, Kraków 2001.

Pluta-Olearnik M., Koncepcja Life - Long Learning - wyzwanie dla kształcenia na poziomie wyższym, http://www.fundacja.edu.pl/organizacja/_referaty/33.pdf, s. 2, [dostęp: 18.05.2015].

Podgórski R.A., Socjologia. Wczoraj. Dziś. Jutro, Wydawnictwo Oświatowe FOSZE, Rzeszów 2006.

Raport dla UNESCO Międzynarodowej Komisji do spraw Edukacji dla XXI wieku pod przewodnictwem Jacques'a Delorsa „Edukacja: jest w niej ukryty skarb”, http:/ / www.unesco. pl/fileadmin/user_upload/pdf/4_Filary_Raport_Delorsa.pdf, [dostęp: 2.01.2018].

Szacka B., Wprowadzenie do socjologii, Oficyna Naukowa, Warszawa 2003.

Szczepański J., Elementarne pojęcia socjologii, Państwowe Wydawnictwo Naukowe, Warszawa 1967.

Suchodolski B., Nowoczesna treść i organizacja wykształcenia ogólnego, Nowa Szkoła, 1958, 4.

Tome E., Human resource development in the knowledge based and services driven economy An introduction, Journal of European Industrial Training, 2011, 35 6, http:/ / www.emeraldinsight.com/doi/pdfplus/10.1108/03090591111150077, [dostęp: 11.12.2017].

Ustawa z 27 lipca 2005 r. Prawo o szkolnictwie wyższym (DzU 2017.02.183).

Wnuk-Lipińska E., Uniwersytet dzisiaj - idea, cele, zadania. Nauka i Szkolnictwo Wyższe, 1996, 8.

Wojnarowska M., Zarządzanie wiedza w organizacji, [w:] Koncepcje zarzadzania. Podręcznik akademicki, red. M. Czerska, A.A. Szpitter, Wydawnictwo C.H. Beck, Warszawa 2010.

Zigler E., Child L. (red.), Socialization and Personality Development, Addison-Wesley, Chicago 1973. 
